\title{
ANALISIS KUALITAS DIET SISWA SEKOLAH DASAR KREATIF HARAPAN BANGSA CIMAHI
}

\author{
Renata Risky M, Sri Subekti' ${ }^{1}$, Cica Yulia ${ }^{2}$ \\ Program Studi Pendidikan Tata Boga, Departemen Pendidikan Kesejahteraan \\ Keluarga, Fakultas Pendidikan Teknologi dan Kejuruan, Universitas Pendididkan \\ Indonesia
}

renatarmaulina@student.upi.edu

\begin{abstract}
Abstrak: Anak sekolah rentan terhadap masalah kekurangan maupun kelebihan gizi. Salah satu faktor penyebab masalah tersebut adalah kualitas konsumsi pangan yang dikonsumsi setiap harinya. Tujuan dalam penelitian ini yaitu untuk mengetahui status gizi siswa, konsumsi pangan siswa serta kualitas diet siswa Sekolah Dasar Kreatif Harapan Bangsa Cimahi. Metode pada penelitian ini yaitu deskriptif kuantitatif dengan desain case study. Populasi sebanyak 75 siswa Sekolah Dasar Kreatif Harapan Bangsa Cimahi. Teknik pengambilan sampel adalah Simple Random Sampling yang digunakan sebanyak 42 siswa mulai dari kelas 4, 5 dan 6 Sekolah Dasar Kreatif Harapan Bangsa Cimahi. Hasil penelitian yang diperoleh adalah sebanyak (12\%) siswa berstatus gizi kurus, (69\%) siswa berstatus gizi normal, sebanyak (17\%) siswa berstatus gizi gemuk dan sebanyak $(2 \%)$ siswa berstatus gizi obesitas. Rata-rata konsumsi makan siswa adalah 2183,7 kal per harinya dengan protein sebanyak 59,6 gram, lemak sebanyak 70,3 gram, kharbohidrat sebanyak 289,9 gram, kalsium sebanyak 679,8 mg, phosfor sebanyak 700,6 mg, vitamin A sebanyak $581 \mathrm{mg}$, vitamin B sebanyak 1,97 mg, dan vitamin C sebanyak $51,6 \mathrm{mg}$. Kualitas diet siswa pada hari sekolah sebanyak $(11,9 \%)$ buruk, $(83,3 \%)$ need improvement dan $(4,8 \%)$ baik. Sedangkan kualitas diet siswa pada hari libur adalah sebanyak (12\%) buruk dan $(88 \%)$ need improvement. Rekomendasi bagi lembaga terkait adalah untuk memberikan pengetahuan dan pendampingan untuk pola makan siswa pada hari sekolah dan pada hari libur bagi ibu untuk memperhatikan makanan yang dikonsumsi anak sehingga menghasilkan pola makan yang baik.
\end{abstract}

Kata Kunci : Kualitas Diet, Sekolah Dasar, Siswa

\section{PENDAHULUAN}

Anak sekolah dasar berusia antara 7 sampai 12 tahun,pada masa ini seorang individu sedang dalam masa pertumbuhan dan perkembangan. Beberapa hal dapat mempengaruhi proses pertumbuhan dan perkembangan seorang individu. Salah satu faktor yang dapat mendorong optimalisasi pertumbuhan dan perkembangan anak usia sekolah adalah asupan gizi yang sehat dan seimbang. Pemenuhan asupan gizi yang sehat dan seimbang setiap harinya bisa didapatkan dari asupan makan atau minuman yang dibagi menjadi 5 waktu makan yaitu sarapan, selingan siang, makan siang, selingan sore dan makan malam. (Farida, 2016)

Tahapan usia anak sekolah dasar merupakan tahap tumbuh kembang yang sangat penting sehingga memerlukan asupan gizi yang baik dan seimbang untuk bekal perkembangan menjadi remaja yang produktif, sehat dan cerdas. Oleh karena itu usia SD dapat dijadikan sebagai media pembawa perubahan bagi pembentukan perilaku gizi bagi dirinya sendiri dan keluarga (Departemen 
Kesehatan RI, 2005). Usia anak adalah usia emas yang menjadi bibit yang menentukan bagi masa depan bangsa. Artinya kualitas SDM generasi muda harus mulai diperhatikan sejak usia anak-anak. Saat ini muncul masalah pada anak usia Sekolah Dasar (SD), yaitu terhambatnya pertumbuhan, menurunnya kecerdasan, menurunnya daya tahan tubuh. Hal tersebut disebabkan karena kurangnya pemenuhan gizi yang baik anak usia SD di Indonesia masih ada yang mengalami gizi buruk terutama pada daerah-daerah pedesaan yang kurang mendapat perhatian dari pemerintah (Depkes, 2011)

Pemberian makanan yang sehat dan bergizi diharapkan dapat menjamin perkembangan dan pertumbuhan anak, pada masa ini anak sebaiknya mendapatkan frekuensi makan yang lebih banyak dibandingkan orang dewasa. Dalam pemberian makanan harus memperhatikan asupan gizi yang seharusnya diberikan agar tubuh tetap sehat. Kebutuhan kalori anak-anak disesuaikan dengan berat badan,usia dan aktifitas anak itu sendiri.Kebutuhan kalori untuk anak usia 7- 9 tahun adalah 1850 kkal .Sedangkan untuk anak laki -laki usia 10-12 tahun membutuhkan energi sebesar 2100 kkal dan untuk anak perempuan usia 10-12 tahun membutuhkan energi sebesar $2000 \mathrm{kkal}$ (AKG,2013)

Studi pada anak-anak menunjukan bahwa pola makan telah mengalami perubahan pada tahun-tahun terakhir. Mereka meminum lebih banyak susu rendah lemak dan non lemak, mengkonsumsi sedikit whole milk dan telur, makan lebih banyak camilan dan lebih suka mengkonsumsi makanan di lingkungan lain dibandingkan di rumah (Ralston, 2008).
Berdasarkan data Riset Kesehatan Dasar (Riskesdas) tahun 2007, prevalensi nasional anak usia sekolah (6-14 tahun), untuk anak laki-laki kurus sebanyak $13,3 \%$ dan anak perempuan kurus sebanyak 10,9\%. Selain masalah anak kurus, terdapat juga masalah anak gemuk yaitu anak usia sekolah gemuk untuk laki-laki sebesar 9,5\% dan 6,4\% untuk perempuan.

Pemenuhan gizi seimbang memiliki berbagai manfaat yang sangat baik bagi anak, bukan hanya peran sebagai pembentukan fisik yang ideal saja tetapi juga memberikan sumber tenaga sebagai penunjang aktifitas anak. Sebagai contoh pada anak yang mengalami kekurangan gizi akan terlihat lemas, kurang bersemangat dan pasif, tentunya hal ini dapat mengganggu kegiatan belajar anak sehingga pembelajaran tidak dapat berjalan secara maksimal serta pada anak yang mempunyai intake makan kurang, kadar glukosa darahnya menurun sehingga pasokan energi untuk kerja otak kurang. Tubuh memecah simpanan glikogen untuk mempertahankan kadar gula normal. Apabila cadangan glikogen habis, tubuh akan kesulitan memasok energi dari glukosa ke otak, yang akhirnya mengakibatkan anak menjadi cepat lelah, badan gemetar dan dapat mengalami penurunan dalam konsentrasi belajar (Sibuea, 2003)

Dalam pelaksanaan pemenuhan gizi seimbang, pemerintah sudah berperan aktif dalam usaha pemenuhan gizi seimbang bagi anak usia Sekolah Dasar, salah satunya hal ini dapat dilihat pada beberapa program pemerintah salah satunya adalah Pemberian Makanan Tambahan Anak Sekolah (PMTAS) dan juga School Feeding di sekolah-sekolah tertentu yang mana school feeding ini 
dilaksanakan berdasarkan asumsi bahwa pendidikan dan pembelajaran bergantung pada gizi yang baik, dan untuk meningkatkan stabilitas fisik antara anak-anak sekolah sebagai bagian dari program perbaikan gizi dan kesehatan, sehingga dapat memperbaiki kualitas kesehatan anak sekolah (WFP, 2008).

Menurut Tri Haryanti (2010), ada beberapa faktor yang mempengaruhi kekurangan gizi pada anak-anak antara lain, kurangnya pengetahuan orang tua mengenai makanan bergizi, status sosial dan ekonomi orang tua. Maka peran orang tua juga sangat penting sebagai kontrol gizi anak-anak dalam lingkungan rumah dan sekolah. Berdasarkan uraian diatas, diketahui masih terdapat banyak masalah terkait asupan gizi anak sekolah.

Uraian latar belakang yang telah penulis paparkan, membuat penulis sebagai mahasiswa Program Studi Pendidikan Tata Boga dengan paket peminatan Dietetika tertarik melakukan penelitian tentang kualitas diet dengan judul " Analisis Kualitas Diet Siswa Sekolah Dasar Kreatif Harapan Bangsa Cimahi”

\section{METODE}

Metode yang digunakan dalam penelitian ini adalah metode deskriptif dengan pendekatan kuantitatif. Penelitian dilaksanakan selama 10 bulan yaitu mulai dari bulan Maret hingga Desember 2019 di Sekolah Dasar Kreatif Harapan Bangsa Cimahi.

Populasi dalam penelitian yaitu siswa Sekolah Dasar Kreatif Harapan Bangsa Cimahi sebanyak 75 siswa. Teknik pengambilan sampel menggunakan Simple Random Sampling, sehingga dihasilkan sebanyak 42 siswa.Instrumen yang digunakan adalah pedoman wawancara untuk mengetahui status gizi siswa menggunakan pengukuran antropometri yang mengacu kepada keputusan Mentri Kesehatan Republik Indonesia Nomer: 1995/MENKES/SK/XII/2010 dan food recall untuk mengetahui kualitas diet siswa yang mengacu kepada HEI (Healty Eating Index).

\section{HASIL DAN PEMBAHASAN}

Hasil penelitian yang dilakukan oleh penulis diperoleh melalui pedoman wawancara untuk mengetahui status gizi siswa menggunakan pengukuran antropometri yang mengacu kepada keputusan Mentri Kesehatan Republik Indonesia Nomer: 1995/MENKES/SK/XII/2010 dan food recall untuk mengetahui kualitas diet siswa yang mengacu kepada HEI (Healty Eating Index).

\begin{tabular}{|c|c|c|}
\hline Karakteristik & $\mathbf{n}$ & $\%$ \\
\hline \multicolumn{3}{|c|}{ Jenis Kelamin } \\
\hline Perempuan & 24 & $57 \%$ \\
\hline Laki-laki & 18 & $43 \%$ \\
\hline Total & $\begin{array}{l}42 \\
\text { Umur }\end{array}$ & $100 \%$ \\
\hline 10 tahun & 15 & $36 \%$ \\
\hline 11 tahun & 16 & $38 \%$ \\
\hline 12 tahun & 11 & $26 \%$ \\
\hline Total & 42 & $100 \%$ \\
\hline Kelas 4 & 14 & $33 \%$ \\
\hline Kelas 5 & 14 & $33 \%$ \\
\hline Kelas 6 & 14 & $33 \%$ \\
\hline Total & $\begin{array}{l}42 \\
\text { Uang jajan }\end{array}$ & $100 \%$ \\
\hline$<$ Rp.5.000 & 12 & $28,5 \%$ \\
\hline $\begin{array}{l}\text { Rp.5.000 - } \\
\text { Rp. } 10.000\end{array}$ & 22 & $52,3 \%$ \\
\hline $\begin{array}{l}\text { Rp.10.000- } \\
\text { Rp.15.000 }\end{array}$ & 3 & $7,1 \%$ \\
\hline$>$ Rp.15.000 & 5 & $11,9 \%$ \\
\hline Total & 42 & $100 \%$ \\
\hline $\operatorname{Max}$ & Rp.20.000 & \\
\hline Min & Rp.4.000 & \\
\hline $\begin{array}{l}\text { Rata-Rata } \\
\pm \text { SD }\end{array}$ & $8.929 \pm 4233,3$ & \\
\hline
\end{tabular}

Tabel 1. Karakteristik Sampel 
Berdasarkan tabel 1 dapat disimpulan bahwa sampel penelitian di Sekolah Dasar Kreatif Harapan Bangsa Cimahi berdasarkan kategori jenis kelamin paling banyak terdapat pada jenis kelamin perempuan yaitu sebanyak $57 \%$. Dari hasi pengumpulan data dapat diketahui bahwa sebagian besar responden berusia 11 tahun (38\%) dan besaran uang jajan sebagian responden sebesar RP.5.000 - Rp. 10.000 sebanyak (22 \%) dengan maksimal uang jajan sebesar Rp.20.000 dan minimal uang jajan sebesar Rp.4.000.

Status gizi siswa Sekolah Dasar Kreatif harapan bagsa terdapat pada gambar 1.

\section{Status Gizi}

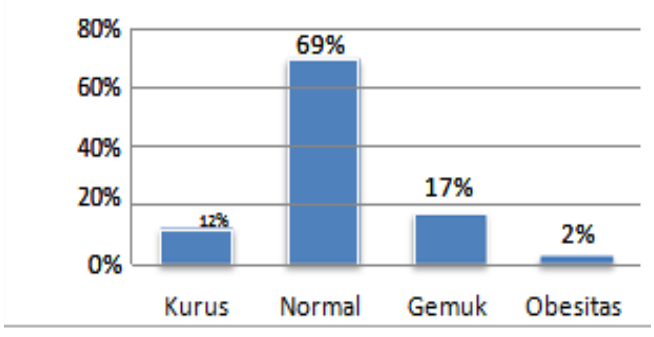

Gambar 1. Status Gizi Siswa

Berdasarkan gambar 1 dapat diketahui berdasarkan indikator indek masa tubuh terhadap umur (IMT/U) didapatkan status gizi sebanyak $12 \%$ siswa berstatus gizi kurus, sebanyak 69 $\%$ siswa berstatus gizi normal, sebanyak $17 \%$ siswa berstatus gizi gemuk dan sebanyak $2 \%$ siswa berstatus gizi obesitas. Sejalan dengan Anggareni (2013) yang menyatakan anak usia sekolah 7-12 tahun memiliki beragam aktifitas sehingga kebutuhan gizinya harus diperhatikan karena pada usia ini anak mudah terpengaruh oleh kebiasaan-kebiasaan di luar keluarga. Pada usia ini anak mulai memilih atau menentukan sendiri makanan yang dikonsumsi ataupun yang disukainya. Kadang-kadang timbul kesulitan yang berlebihan terhadap salah satu makanan tertentu yang disebut Food Faddism sehingga dapat mempengaruhi status gizi anak itu sendiri.

Status gizi siswa dapat mempengaruhi konsumsi asupan zat gizi siswa itu sendiri berdasarkan status gizi siswa maka di dapatkan data sebagai berikut

\begin{tabular}{|c|c|c|c|}
\hline Status gizi & Zat Gizi & \multicolumn{2}{|c|}{ Konsumsi } \\
\hline Kurus & $\begin{array}{l}\text { Energi (kkal) } \\
\text { Protein(gram) }\end{array}$ & $\begin{array}{c}\text { Hari Sekolah } \\
1875,2 \pm 109,7 \\
51,6 \pm 6,8\end{array}$ & $\begin{array}{c}\text { Hari Libur } \\
1837,6 \pm 85,9 \\
50,8 \pm 6,4\end{array}$ \\
\hline Normal & $\begin{array}{l}\text { Energi (kkal) } \\
\text { Protein(gram) }\end{array}$ & $\begin{array}{c}2177,9 \pm 93,5 \\
60,7 \pm 4,8\end{array}$ & $\begin{array}{c}2184,9 \pm 133,4 \\
57,2 \pm 5,2\end{array}$ \\
\hline Gemuk & $\begin{array}{l}\text { Energi (kkal) } \\
\text { Protein(gram) }\end{array}$ & $\begin{array}{c}2343,3 \pm 90,7 \\
63,5 \pm 4,3\end{array}$ & $\begin{array}{c}2295,5 \pm 131,1 \\
63,1 \pm 3,9\end{array}$ \\
\hline Obesitas & $\begin{array}{l}\text { Energi (kkal) } \\
\text { Protein(gram) }\end{array}$ & $\begin{array}{c}2678,5 \pm 152 \\
75 \pm 5,6\end{array}$ & $\begin{aligned} 2456 & \pm 161,9 \\
74 & \pm 1,4\end{aligned}$ \\
\hline Rata-Rata & $\begin{array}{l}\text { Energi (kkal) } \\
\text { Protein(gram) }\end{array}$ & $\begin{array}{c}2189,6 \pm 191,4 \\
60,7 \pm 6,7\end{array}$ & $\begin{array}{c}2151,3 \pm 217,5 \\
57,3 \pm 8,05\end{array}$ \\
\hline
\end{tabular}

Tabel 2 Rata Rata Konsumsi Energi dan Protein

Dari tabel 2 dapat disimpulkan bahwa rata-rata konsumsi energi dan protein siswa Sekolah Dasar Kreatif Harapan Bangsa Cimahi adalah 2189,6 $\pm 191,4$ kkal dan $60,7 \pm 6,7$ gram untuk hari sekolah sedangkan $2153 \pm 217,5$ kkal dan $57 \pm 8,05$ gram untuk hari libur. Konsumsi energi dan protein hari sekolah lebih tinggi dibandingkan konsumsi energi dan protein hari libur 
dikarenakan siswa Sekolah Dasar Kreatif Harapan Bangsa Cimahi mengadakan program school feeding dimana jumlah dan konsumsi makan siang siswa di sekolah lebih besar dan lengkap komposisinya (nasi, lauk pauk, sayur dan buah ). Sedangkan menu makan dirumah komposisinya tidak lengkap (nasi, lauk pauk, sayur dan buah ) dan besar porsinya tergantung keinginan siswa dan juga konsumsi energi dan protein di hari sekolah lebih tinggi dibandingkan hari libur dikarenakan pada hari sekolah siswa banyak mengkonsumsi jajanan sekolah.

\begin{tabular}{cccc}
\hline Status gizi & \multicolumn{1}{c}{ Zat Gizi } & \multicolumn{2}{c}{ Konsumsi } \\
\hline & & Hari Sekolah & HariLibu \\
Kurus & Lemak (gr) & $42,8 \pm 11,3$ & $39,6 \pm 7,1$ \\
Normal & Lemak (gr) & $73,1 \pm 6,6$ & $72,2 \pm 5,6$ \\
Gemuk & Lemak (gr) & $76,6 \pm 4,3$ & $75,7 \pm 5,2$ \\
Obesitas & Lemak (gr) & $84 \pm 7,07$ & $84 \pm 7,07$ \\
Rata-rata & Lemak(gr) & $68,5 \pm \mathbf{1 3 , 5}$ & $68,1 \pm \mathbf{1 4 , 9}$ \\
\hline
\end{tabular}

Tabel 3 Rata-Rata Konsumsi Lemak

Dari tabel 3 dapat disimpulkan bahwa rata-rata konsumsi lemak siswa Sekolah Dasar Kreatif Harapan Bangsa Cimahi adalah 68,5 \pm 13,5 gram untuk hari sekolah sedangkan $68,1 \pm 14,9$ gram untuk hari libur. Konsumsi lemak pada hari sekolah sedikit lebih tinggi dibandingkan konsumsi lemak hari libur .

\begin{tabular}{|c|c|c|c|c|c|c|}
\hline \multirow[t]{3}{*}{ Zat gizi } & \multicolumn{5}{|c|}{ Status gizi } & \multirow[t]{2}{*}{ Rata-Rata } \\
\hline & & urus & Normal & Gemuk & Obesitas & \\
\hline & \multicolumn{5}{|c|}{ Hari sekolah } & \multirow[b]{2}{*}{$909,1 \pm 111$} \\
\hline Kalsium (mg) & 650 & $\pm 89,2$ & $939,5 \pm 45,4$ & $957,3 \pm 67,3$ & $984,5 \pm 3,5$ & \\
\hline Fosfor (mg) & 643,4 & \pm 216 & $949 \pm 75,8$ & $975,3 \pm 66$ & $1008,5 \pm 19,5$ & $918,4 \pm 143,1$ \\
\hline Zat Besi (mg) & 8 & $\pm 2,6$ & $15,9 \pm 3,5$ & $21,6 \pm 1,3$ & $27 \pm 1,4$ & $16,3 \pm 5,3$ \\
\hline \multicolumn{7}{|c|}{ Hari libur } \\
\hline Kalsium (mg) & 633,2 & $\pm 47,2$ & $934,7 \pm 50,7$ & $945,3 \pm 29$ & $1027 \pm 63,3$ & $911,6 \pm 100$ \\
\hline Fosfor (mg) & 614 & $\pm 4,8$ & $937,0 \pm 34,2$ & $976,1 \pm 56$ & $1045 \pm 33,4$ & $917,5 \pm 114$ \\
\hline Zat Besi (mg) & 8,2 & $\pm 2,9$ & $19 \pm 4,6$ & $26,8 \pm 1,4$ & $28,5 \pm 2,1$ & $19,7 \pm 6,4$ \\
\hline
\end{tabular}

Tabel 4 Rata-Rata Konsumsi Mineral
Dari Tabel 4 dapat disimpulkan dapat disimpulkan bahwa rata-rata konsumsi mineral siswa Sekolah Dasar Kreatif Harapan Bangsa Cimahi untuk zat gizi mineral adalah $909,1 \pm 111 \mathrm{mg}$ pada hari sekolah dan 911,6 $\pm 100 \mathrm{mg}$ pada hari libur yang mana konsumsi kalsium lebih tinggi pada hari libur dibandingkan hari sekolah. Sedangkan untuk zat gizi fosfor sebanyak 918,4 $\pm 143,1 \mathrm{mg}$ pada hari sekolah dan 917,5 \pm 114 pada hari libur yang mana konsumsi fosfor lebih tinggi pada hari sekolah dibandingkan hari libur. Dan sebanyak $16,3 \pm 5,3 \mathrm{mg}$ zat besi pada hari sekolah dan 19,7 $\pm 6,4 \mathrm{mg}$ zat besi pada hari libur yang mana konsumsi zat besi lebih tinggi pada hari libur dibandingkan hari sekolah.Konsumsi Mineral ini sangatlah penting untuk perkembangan anak. Hal ini sejalan dengan Almatsier S (2000) yang menyatakn bahwa selama masa pertumbuhan dan perkembangan anak memerlukan kalsium, fosfor, magnesium, kalium, zat besi, natrium, fluor, seng, iodium, mangan, tembaga, kromiun, dan selenium.Kesemua zat gizi mikro tersebut punya peran yang sama besarnya untuk menunjang segala fungsi tubuh anak, khususnya selama tumbuh kembangnya,seperti mineral kalsium, yang baik untuk mengoptimalkan pertumbuhan tulang anak.Selain memberikan kepadatan, kalsium juga menjaga tulang agar tidak mudah keropos. Bahkan, mineral yang satu ini dapat membantu menjaga fungsi jantung, pembekuan darah, serta otot, meski dalam jumlah sedikit. Makanan sumber utama kalsium ada di 
semua susu dan produk olahannya,selain itu sumber mineral terdapat disemua jenis buah dan sayuran.

\begin{tabular}{|c|c|c|c|c|c|}
\hline Zat gizi & \multicolumn{4}{|c|}{ Status gizi } & Rata-Rata \\
\hline & Kurus & $\begin{array}{l}\text { Normal } \\
\text { Hari se }\end{array}$ & $\begin{array}{l}\text { Gemuk } \\
\text { ekolah }\end{array}$ & Obesitas & \\
\hline Vitamin A & $466 \pm 54,5$ & $600 \pm 18,9$ & $632,3 \pm 69,1$ & $639 \pm 19,7$ & $593,8 \pm 5,3$ \\
\hline Vitamin B & $1,4 \pm 1,03$ & $1,8 \pm 0,4$ & $2,6 \pm 0,5$ & $2,5 \pm 0,7$ & $1,9 \pm 0,6$ \\
\hline Vitamin C & $30 \pm 11,8$ & $\begin{array}{r}52,2 \pm 6,3 \\
\text { Hari }\end{array}$ & $\begin{array}{l}63,5 \pm 14,9 \\
\text { libur }\end{array}$ & $72,5 \pm 2,1$ & $52,4 \pm 13$ \\
\hline Vitamin A & $512,2 \pm 7,4$ & $561,8 \pm 84,8$ & $630 \pm 36$ & $644 \pm 12,7$ & $568,2 \pm 85,5$ \\
\hline Vitamin B & $1,7 \pm 0,5$ & $1,9 \pm 0,2$ & $2,1 \pm 0,9$ & $2,5 \pm 0,7$ & $1,9 \pm 0,5$ \\
\hline
\end{tabular}

Tabel 5 Rata-Rata Konsumsi Vitamin

Dari Tabel 5 diatas dapat disimpulkan bahwa rata-rata konsumsi vitamin siswa Sekolah Dasar Kreatif Harapan Bangsa Cimahi untuk zat gizi vitamin A adalah 593,8 $\pm 5,3 \mathrm{mg}$ pada hari sekolah dan 568,2 $\pm 85,5 \mathrm{mg}$ pada hari libur. Sedangkan untuk vitamin B sebanyak $1,9 \pm 0,6 \mathrm{mg}$ pada hari sekolah dan $1,9 \pm 0,5$ pada hari libur. Dan sebanyak 52,4 $\pm 13 \mathrm{mg}$ vitamin $\mathrm{C}$ pada hari sekolah dan 50,9 $\pm 13,1 \mathrm{mg}$ vitamin $C$ pada hari libur. Sehingga konsumsi vitamin $\mathrm{A}, \mathrm{B}$ dan $\mathrm{C}$ siswa lebih tinggi pada haari sekolah dibandingkan hari libur.

Kualitas diet siswa Sekolah Dasar Kreatif Harapan Bangsa Cimahi terdapat pada Tabel

\begin{tabular}{clllll}
\hline $\begin{array}{c}\text { Kategori } \\
\text { HEI }\end{array}$ & Skor & \multicolumn{2}{c}{$\begin{array}{c}\text { Hari } \\
\text { Haki libur }\end{array}$} \\
\cline { 3 - 6 } Buruk & $\leq 50$ & 5 & 11,9 & 4 & \multicolumn{2}{c}{ Hari } \\
$\begin{array}{c}\text { Need } \\
\text { Nekolah }\end{array}$ & $51-80$ & 35 & 83,3 & 37 & 88 \\
$\begin{array}{c}\text { imprvment } \\
\text { Baik }\end{array}$ & $>80$ & 2 & 4,8 & 0 & 0 \\
Total & & $\mathbf{4 2}$ & $\mathbf{1 0 0}$ & $\mathbf{4 2}$ & $\mathbf{1 0 0}$ \\
\hline
\end{tabular}

Tabel 6. Skor Kualitas Konsumsi

Pangan berdasarkan HEI
Berdasarkan Tabel 6 menunjukan kategori kualitas konsumsi makan berdasarkan HEI, dengan hasil sebanyak $11,9 \%$ untuk hari sekolah dan sebanyak $12 \%$ untuk hari libur yang menunjukan hasil buruk,sedangkan $83 \%$ pada hari sekolah dan $88 \%$ pada hari libur menunjukan hasil need improvement atau memerlukan perbaikan ,dan sebanyak 4,8 \%pada hari sekolah menunjukan hasil baik.

Maka secara umum kualitas konsumsi pangan siswa Sekolah Dasar Kreatif Harapan Bangsa masih belum memenuhi kaidah gizi seimbang dan masih memerlukan perbaikan untuk memenuhi gizi seimbang. Hal ini menunjukan bahwa kualitas konsumsi pangan siswa pada hari sekolah lebih baik dibandingkan hari libur. Hal ini sejalan dengan Ralston (2008) yang menunjukan bahwa pola makan telah mengalami perubahan pada tahuntahun terakhir. Mereka meminum lebih banyak susu rendah lemak dan non lemak, mengkonsumsi sedikit whole milk dan telur, makan lebih banyak camilan dan lebih suka mengkonsumsi makanan di lingkungan lain dibandingkan di rumah. Sehingga perbaikan kualitas konsumsi pangan atau diet yang perlu dilakukan yaitu meningkatkan konsumsi sayur, buah, protein nabati dan sumber $\mathrm{Fe}$, mengurangi konsumsi pangan sumber karbohidrat dan mempertahankan konsumsi protein hewani, lemak dan juga keragaman. 


\section{KESIMPULAN}

Hasil penelitian menunjukan Status gizi pada siswa Sekolah Dasar Kreatif Harapan Bangsa Cimahi berdasarkan indikator indeks masa tubuh terhadap umur (IMT/U) menunjukan persentase status gizi sebanyak $12 \%$ responden berstatus gizi kurus, 69\% responden berstus gizi normal, 17\% responden berstatus gizi gemuk dan sebanyak $2 \%$ berstus gizi obesitas.

Konsumsi pangan siswa Sekolah Dasar Kreatif Harapan Bangsa Cimahi menunjukan bahwa rata-rata konsumsi makan siswa sebanyak 2183,7 kal per harinya dengan protein sebanyak 59,6 gram, lemak sebanyak 70,3 gram, kharbohidrat sebanyak 289,9 gram, kalsium sebanyak 679,8 mg, phosfor sebanyak 700,6 mg, vitamin A sebanyak $581 \mathrm{mg}$, vitamin B sebanyak $1,97 \mathrm{mg}$, dan vitamin $\mathrm{C}$ sebanyak 51,6 mg.

Kualitas diet siswa Sekolah Dasar Kreatif Harapan Bangsa Cimahi berdasarkan Healty Eating Index (HEI) menunjukan bahwa Kualitas diet siswa pada hari sekolah sebanyak $(11,9 \%)$ buruk, $(83,3 \%)$ need improvement dan $(4,8 \%)$ baik. Sedangkan kualitas diet siswa pada hari libur adalah sebanyak $(12 \%)$ buruk dan (88\%) need improvement.Sehingga secara umum kualitas konsumsi pangan siswa Sekolah Dasar Kreatif Harapan Bangsa masih belum memenuhi kaidah gizi seimbang dan masih memerlukan perbaikan untuk memenuhi gizi seimbang.

Rekomendasi terkait dengan kualitas diet siswa Sekolah Dasar Kreatif Harapan Bangsa Cimahi masih kurang, sehingga bagi pihak sekolah diharapkan untuk memperhatikan dan memberikan pengetahuan serta asupan makan terutama makan siang pada anak agar memenuhi gizi yang dibutuhkan. Selain itu sebaiknya ibu memperhatiakan makanan yang dikonsumsi oleh anak terkait frekuensi makan, kuantitas makan, kualitas makan, variasi makan serta jadwal makan bagi anak sehingga akan menghasilkan kualitas diet yang baik dengan cara membaca ataupun bertanya kepada pihak terkait mengenai makanan yang baik bagi anak sekolah

\section{REFERENSI}

Almatsier, S. (2000). Prinsip Dasar Ilmu Gizi. Jakarta: PT.Gramedia Pustaka Utama.

Anggraini, F. (2013). Faktor-fakt0r yang Berhubungan dengan Status Gizi Siswa Sekolah Dasar di Kecamatan Pancoran. Jakarta: Skripsi.FKM UI.

AKG. (2013). Permenkes RI No 75 Tahun 2013 tentang Angka Kecukupan Gizi yang Dianjurkan bagi Bangsa Indonesia. Mentri Kesehatan RI. Jakarta.

Depkes, R. (2005). Undang-Undang Republik Indonesia Nomor : 23 tahun 2005 Tentang Kesehatan; Jakarta Hal 1. Fisioterapi Indonesia. Jakarta.

Depkes, R. D. (2011). Target Tujuan Pembangunan MDGs. Direktorat Jendral Kesehatan Ibu dan Anak. Jakarta.

Farida, I. (2016). Analisis Pengetahuan Sarapan Sehat Siswa SD Negeri Lengkong Besar. Bandung: Universitas Pendidikan Indonesia.

RISKESDAS. (2007). Riset Kesahatan Dsar. Jakarta: Badan Penelitian dan Pengembangan Kesehatan, Departemen Kesehatan, Republik Indonesia.

Sibuea, P. (2003). Antioksidan Senyawa Ajaib Penangkal 
Penuaan Dini, Sinar Harapan.

Yogyakarta.

Tri, H. (2010). Status Gizi Kelas IV, V dan VI di SD Negeri 2 Sadang Kulon Sadang Kebumen Tahun 2009/20010. Yogyakarta : Skripsi FIK UNY.

WFP. (2008). A Food Insecurity Atlas of Indonesia. Food Security Council. Ministry of Agriculture, Republic of Indonesia and WFP. Jakarta. 